\title{
PENGEMBANGANAN KURIKULUM SEKOLAH MINGGU
}

\author{
Oleh : Pdt. Adolf Edwin Ratag, S.Th., M.Pd.K ${ }^{1}$ \\ Kepala UPT Perpustakaan
}

\begin{abstract}
ABSTRAK
Anak-anak adalah pribadi yang sangat penting. Siapa mereka di masa depan, dan Gereja di masa depan sangat ditentukan oleh bagaimana kita melayani anak-anak di masa kini; karena itu pelayanan kepada mereka tidak boleh dianggap remeh. Kurikulum merupakan salah satu hal yang sangat penting dalam proses mempersiapkan dan memantapkan kapasitas anak, baik secara mental maupun secara spiritual. Visi dan misi gereja sangat penting menjadi acuan dalam menyusun kurikulum Sekolah Minggu. Namun demikian, ada 5 faktor yang menjadi alasan yang perlu dipertimbangkan, yaitu alasan teologis, paedagogis, keadaan, kebudayaan dan misioner. Kurikulum dikembangkan berdasarkan keyakinan bahwa Alkitab adalah firman Allah, sehingga memuat sebanyak mungkin isi Alkitab; disusun dengan mempertimbangkan perkembangan jiwa anak; dan memikiran metode yang kreatif, bervariasi dan menarik. Penyusunan kurikulum sangat berhubungan dengan dua pertanyaan penting: Siapa? Apa? Para penyusun kurikulum harus bertanya: Untuk siapa? Untuk mereka yang bagaimana?Untuk mereka yang dimana?Kontennya apa?Untuk kapan? Khusus pertanyaan yang terakhir berkaitan erat dengan kalender gerejawi Hal yang terpenting dalam penyusunan kurikulum adalah anak-anak itu sendiri.
\end{abstract}

\section{Kata Kunci : Kurikulum, Siapa, Apa, Anak-anak, Masa Depan dan Gereja}

${ }^{1}$ Dosen pada Program Studi Pendidikan Agama Kristen STT Erikson-Tritt Manokwari. 


\section{A. PENDAHULUAN}

Gereja sebagai organisasi maupun sebagai Tubuh Kristus terdiri dari anak-anak dan orang dewasa. Gereja sebagai organisasi bertanggung jawab terhadap pembinaan warganya. Banyak gereja begitu bersemangat menyusun dan melaksanakan berbagai program, termasuk program pembinaan warga gereja. Ironisnya, dari sekian banyak program, jarang yang menyentuh pelayanan kepada anak-anak, atau yang umum dikenal sebagai pelayanan Sekolah Minggu. Itu sangat mudah untuk dibuktikan, antara lain, dengan pertanyaan: "Berapa persen dari anggaran gereja yang disiapkan untuk pelayanan anak?" Gereja harus merencanakan anggaran pelayanan yang besar untuk pelayanan anak. Untuk apa? Untuk banyak hal, termasuk di dalamnya berkaitan dengan pengembangan kurikulum dan implementasinya dalam pelayanan Sekolah Minggu.

Pelayanan kepada anak-anak Sekolah Minggu, khususnya menyangkut pembinaan yang berkaitan proses pembelajaran dibutuhkan perencanaan yang matang. Tidak jarang dalam pelayanan kepada kelompok ini dilakukan sekedarnya saja. Agenda acara: menyanyi, berdoa dan mendengar cerita. Berhubungan dengan cerita atau bahan pelajaran Alkitab, acap kali tanpa tujuan yang jelas. Pengasuh atau guru Sekolah Minggu akan bercerita atau mengajar sesuai keinginannya saja yang mungkin tanpa mempertimbangkan susunan bahan-bahan pada setiap pertemuan. Ini sesuatu yang biasa. Syukur ada yang mau mengajar.

Namun demikian, pelayanan yang sekedarnya sangat berbahaya untuk masa depan mereka dalam menghadapi dan menjalani kehidupan "dunia." Pada gilirannya akan sangat berdampak pada perkembangan gereja di masa depan. Anak-anak harus mendapati pelayanan yang berkualitas, yang dipersiapkan secara terencana dan sungguh-sungguh. Pelayanan itu adalah pelayanan yang datang dari hati para pengasuh atau guru Sekolah Minggu yang terpanggil untuk melayani anak-anak dengan hati. Jika demikian, pastilah mereka akan mendoakan, memikirkan dan menggumuli pelayanan itu.

Salah satu dari upaya mengelola pelayanan yang maksimal, yang berdampak pada perkembangan kapasistas mental dan spiritual anakanak Sekolah Minggu adalah pengembangan atau penyusunan kurikulum Sekolah minggu. Materi ini secara singkat dan sederhana akan membahas hal-hal yang berkaitan dengan prinsip-prinsip 
pengembangan kurikulum, antara lain tentunya dimulai dengan pengertian kurikulum itu sendiri, untuk siapa, untuk siapa yang bagaimana dan untuk siapa di mana?

\section{B. PRINSIP-PRINSIP PENGEMBANGAN KURIKULUM SEKOLAH MINGGU}

Dunia anak-anak adalah dunia yang sangat menarik. Keceriaan dan kegembiraan ada di situ. Mereka suka mencari tahu. Mereka senang dengan hal-hal yang baru. Paulus Lie secara sederhana memberikan masukan yang sangat sederhana tetapi penting sekali. Pada bagian awal bukunya yang berjudul Mengajar Sekolah Minggu Yang Kreatif ia tuliskan demikian: "Yang paling utama dari seluruh usaha mengembangkan Sekolah Minggu (SM), yaitu mengupayakan agar setiap acara SM (setiap minggu) selalu menarik! Dengan demikian, SM menjadi acara yang dinamis, kreatif dan sesuai dengan dunia anak-anak masa kini. $^{2}$

Dari pernyataan di atas, dalam rangka pengembangan kurikulum, para guru Sekolah Minggu tidak boleh terjebak pada "kekakuan" teoriteori pengembangan kurikulum, tetapi juga tidak bisa mengabaikan begitu saja. Teori-teori dimaksud perlu diperhatikan tanpa mengabaikan hal-hal yang terkait dengan konteks dunia anak-anak.

\section{Memahami Pengertian Kurikulum Sekolah Minggu}

Sehubungan dengan penyusunan atau pengembangan kurikulum, ada baiknya kita memperhatikan beberapa definisi atau pengertian kurikulum. Menurut Nasution, "Lazimnya kurikulum dipandang sebagai suatu rencana yang disusun untuk melancarkan proses belajarmengajar ..."3 Penekanannya pada "rencana" dan "proses." Dua kata kunci ini penting sekali untuk menegaskan bahwa kurikulum disusun sebagai satu bagian dari rencana pembelajaran, dan pembelajaran itu

\footnotetext{
${ }^{2}$ Paulus Lie, Mengajar Sekolah Minggu Yang Kreatif (Yogyakarta: Penerbit Yayasan ANDi, 1997), hlm. 1.

${ }^{3}$ S. Nasution, Kurikulum Dan Pengajaran (Jakarta: PT Bumi Aksara, 1999), hlm. 5 .
} 
sendiri merupakan suatu "proses" dengan pertimbangan-pertimbangan khusus, baik menyangkut "siapa," "apa" dan "bagaimana."

Sukmadinata memaparkan berbagai pandangan tentang kurikulum, antara lain yang mengatakan bahwa kurikulum itu adalah kumpulan mata pelajaran; kemudian kurikulum dipahami sebagai isi dan pengalaman belajar. ${ }^{4}$ Sama seperti pendapat Nasution, Sukmadinata juga menyimpulkan pendapat para pakar dengan mengatakan bahwa "Kurikulum merupakan suatu rencana yang memberi pedoman atau pegangan dalam proses kegiatan belajar-mengajar."5

Sehubungan dengan pengertian kurikulum, disamping pendapat para ahli yang disimpulkan kedua penulis di atas, rumusan Saylor, Alexander dan Lewis (1981) seperti yang dikutip Kristianto dari Curiculum Planning for Better Teaching and Learning, sepatutnya sebuah kurikulum mempertimbangkan empat kategori berikut, yaitu rencana pelajaran atau bahan-bahan pelajaran, rencana pengalaman belajar, rencana tujuan pendidikan yang hendak dicapai dan rencana kesempatan belajar. ${ }^{6}$

Dalam rangka pengembangan kurikulum juga harus dipahami bahwa kurikulum disusun dengan maksud menjadi pedoman yang benar-benar terencana untuk memperlancar proses kegiatan belajarmengajar. Enklaar dan Homrighausen menjelaskan bahwa istilah curriculum pada dasarnya berarti lapangan perlombaan, dimana penekanannya, yaitu seperti sebuah perlombaan ada titik tertentu untuk mulai dan ada titik tertentu untuk berakhir. Dalam artian bahwa kurikulum adalah suatu proses perjalanan dari permulaan sampai tamat dijalani sebagai suatu perjalanan yang lengkap dan teratur. ${ }^{7}$

Pendapat Enklaar dan Homrighausen di atas sejalan dengan pengertian-pengertian sebelumnya, yaitu menekankan kepada perencanaan yang teratur, yang terorganisir dengan tujuan yang jelas. Karena itu, seperti yang dikatakan Partin, "Tujuan setiap pelajaran

${ }^{4}$ Nana Syaodih Sukmadinata, Pengembangan Kurikulum Teori dan Praktek (Bandung: Penerbit PT Remaja Rosdakarya, 2001), hlm. 4-5.

${ }^{5}$ Ibid.

${ }^{6}$ Paulus Lilik Kristianto, Prinsip Dan Praktik Pendidikan Agama Kristen (Yogyakarta: Penerbit ANDI, 2008), hlm. 35.

${ }^{7}$ I. H. Enklaar dan E. G. Homrighausen, Pendidikan Agama Kristen (Jakarta: PT BPK Gunung Mulia, 2011), hlm. 87-88. 
adalah perubahan - transformasi yang disengaja."8 Maksudnya, upaya pengembangan atau penyusunan kurikulum dalam perencanaan harus benar-benar mempertimbangkan banyak hal.

Dengan demikian, secara sederhana kurikulum Sekolah Minggu yang dimaksud adalah rencana pelajaran yang disusun dengan tujuan menjadikan perserta didik sebagai murid Kristus (Mat. 28:18-20) yang tumbuh dewasa dalam Kristus (Ef. 4:11-15), yang didasarkan pada Alkitab. Kendati demikian, kurikulum Sekolah Minggu juga harus mempertimbangkan hal-hal seperti yang dibahas berikut ini.

\section{Mempertimbangkan Konteks Anak-anak}

Pengembangan kurikulum tidak bisa hanya memikirkan soal susunan pokok-pokok ajaran dan kontennya saja. Memang konten atau isi materi itu penting, entah itu dikaitkan dengan kalender gereja atau atau visi-misi gereja; akan tetapi, secara umum dalam menyusun sebuah kurikulum, khususnya kurikulum Sekolah Minggu harus mempertimbangakan hal-hal yang berkaitan dengan dunia anak-anak. Di mana anak-anak itu berada: tempat tinggalnya? denominasinya? dan kelompok umurnya?

\subsection{Konteks Dunia Sekitar Anak}

Konteks dunia di sekitar anak-anak adalah konteks yang secara langsung dan tidak langsung berhubungan dengan di mana anak itu berada, tinggal dan beraktivitas. Konteks di sekitar anak sepatutnya menjadi bahan pertimbangan karena akan sangat mempengaruhi tujuantujuan yang direncanakan berhubungan siapa anak-anak itu di masa yang akan datang.

Menurut Riemer, sedikitnya ada lima faktor yang harus diperhatikan. Kelima faktor ini akan sangat menentukan metode dan susunan bahan atau materi ajar. ${ }^{9}$ Adapun kelima faktor itu adalah sebagai berikut:

${ }^{8}$ Ronald L. Partin, Kiat Nyaman Mengajar Dalam Kelas (Jakarta: PT Indeks, 2009), hlm. 76.

${ }^{9}$ G. Riemer, Ajarlah Mereka: Pedoman Ilmu Katekese (Jakarta: Yayasan Komunikasi Bina Kasih / OMF, t.t), hlm. 162. 
- Alasan-alasan Teologis. Alasan teologis sangat erat kaitannya dengan pokok-pokok iman yang diyakini oleh denominasi gereja yang bersangkutan. Kebanyakan gereja protestan dalam urutan kurikulumnya menekankan dan mengajarkan kebenaran oleh kasih karunia saja.

- Alasan-alasan Pedagogis. ${ }^{10}$ Ini menyangkut metode yang dirancang menurut prinsip-prinsip didaktis yang baik, serta mementingkan tahap-tahap psikologi belajar.

- Alasan-alasan Keadaan. Keadaan dapat mempengaruhi cara kerja, frekuensi (kekerapan), susunan dan jumlah bahan pelajaran.

- Alasan-alasan Kebudayaan. Untuk alasan ini diperlukan kejelian atau ketelitian agar ajaran Alkitab yang adalah firman Tuhan tetap terjaga kemurniannya.

- Alasan-alasan Misioner. Hal ini berkaitan dengan pemahaman kelompok yang akan menerima aplikasi kurikulum dimaksud. Apakah mereka orang Kristen baru sama sekali, atau simpatisan, atau orang-orang lama? ${ }^{11}$

Dari pandangan ini, berhubungan dengan alasan pertama erat kaitannya dengan "konten" atau "isi" kurikulum itu sendiri. Sedangkan alasan kedua sampai kelima lebih cenderung terkait kepada si peserta didik itu sendiri. Laufer dan Dyck dalam menyusun kurikulum Suara Sekolah Minggu (SSM) menampilkan 4 ciri khas, yaitu:

- Mengakui Alkitab sebagai Firman Allah.

- Meliputi sebanyak mungkin isi Alkitab.

- Sedekat mungkin pada pengertian anak.

- Memberi kesukaan belajar-mengajar melalui metode yang bervariasi dan kreatif. ${ }^{12}$

\footnotetext{
${ }^{10}$ Alasan paedagogis ini akan dibahas secara khusus pada pokok bahasan berikut.

${ }^{11}$ Riemer, Ajarlah Mereka: Pedoman Ilmu Katekese, hlm. 161-162.

${ }^{12}$ Ruth Laufer dan Anni Dyck, Pedoman Pelayanan Anak 2 (Batu Malang: YPPII Departemen Pembinaan Anak dan Pemuda, t.t.), hlm. 15.
} 
Dari pendapat Riemer, Laufer dan Dyck di atas dapat disimpulkan bahwa dalam penyusunan kurikulum itu sendiri sangat berhubungan dengan dua hal penting, yaitu:

- Kurikulumnya untuk siapa?

- Kontennya apa?

Dari kedua pernyataan ini dimunculkan pertanyaan-pertanyaan lain, seperti: Bagaimana cara (metode, media dan lainnya).

\subsection{Konteks "Siapa"}

Dunia dalam diri anak-anak berkaitan erat dengan pertanyaan "siapa?" Penekanannya lebih kepada perkembangan jiwa anak-anak. Seperti yang dikatakan Setiawani, "Seorang guru yang berhasil harus dapat memahami perkembangan jiwa murid, karena murid mempunyai ciri khas yang bersifat umum dalam usia mereka masing-masing . . ." Sejalan dengan itu, pengembang atau penyusun kurikulum pun harus mempertimbangkan kekhasan dari setiap kelompok umur.

Jadi, dari pertanyaan "untuk siapa?" sepatutnya para pengembang kurikulum Sekolah Minggu harus menyadari bahwa peserta didik Sekolah Minggu memiliki tingkatan umur yang berbeda dan pasti memiliki karakter dan kebutuhan yang berbeda pula. Untuk itu, penting untuk dipahami hal-hal yang berkaitan dengan karakter dan kebutuhan anak pada setiap tingkatan umur. Dari pemahaman ini, para pengembang kurikulum dapat memikirkan tentang materi yang tepat, jumlah waktu yang sesuai; metode, teknik atau gaya yang menarik; media pembelajaran yang tepat, pengelolaan ruangan yang pas dan sesuai dengan kelompok umur.

Karakter diartikan watak, tabiat, pembawaan atau kebiasaan. ${ }^{13}$ Sedangkan karakteristik berarti ciri khas, bentuk watak, karakter yang dimiliki oleh setiap indivisu, corak tingkah laku atau tanda khusus. ${ }^{14}$ Kartini Kartono dan Dali Gulo mengartikan character sebagai karakter atau waktak, yaitu "kepribadian ditinjau dari titik tolak etis atau moral

${ }^{13}$ Widodo, "Karakter," dalam Kamus Ilmiah Populer (Yogyakarta: Penerbit Absolut, 2001), hlm. 277.

${ }^{14}$ Ibid. 
biasanya mempunyai kaitan dengan sifat-sifat yang relatif tetap."15 Sedangkan menurut Chaplin, salah satu pengertian character adalah "suatu kualitas atau sifat yang tetap terus-menerus dan kekal yang dapat dijadikan ciri untuk mengidentifikasi seorang pribadi . .."16

Dalam materi ini akan dipaparkan kepribadian, yaitu apa yang menjadi ciri khas atau karakter anak-anak berdasarkan tingkatan umur. Setiawani mengatakan: “. . . guru yang berhasil harus dapat memahami perkembangan jiwa murid, karena murid mempunyai cici khas yang bersifat umum, ciri khas mental, keadaan emosi dan pergaulan serta pertumbuhan rohaninya." 17

Guru Sekolah Minggu, bukan hanya mengajar tetapi juga sebagai pengembang kurikulum harus benar-benar menyadari bahwa ciri khas anak-anak erat hubungannya dengan kebutuhan mereka. Kesadaran ini diimplementasikan dalam pengembangan kurikulum, baik berhubungan dengan tema-tema, isi materi, strategi dan media yang dapat digunakan. Akan tetapi harus dipahami juga bahwa berbicara mengenai ciri khas anak itu sangat luas. Karena begitu luasnya pembahasan mengenai karakter anak-anak, maka yang dikedepankan adalah hal-hal yang bersifat umum. Anak-anak yang dimaksud ialah dari usia 0 - 12 tahun.

Kebutuhan atau dalam bahasa Inggris: need, berarti "setiap kekurangan yang ada pada individu, baik yang merupakan kegemaran maupun kebutuhan fisiologis; persyaratan-persyaratan untuk terus hidup atau untuk penyesuaian optimal terhadap lingkungan. ${ }^{18}$

Artinya, apabila itu tidak terpenuhi maka akan menimbulkan perasaan "ada yang kurang." Konsekuensi logisnya adalah ia akan terus mencari yang kurang tersebut dengan caranya sendiri. Chaplin mengatakan, kebutuhan adalah "satu substansi selluler yang harus dimiliki oleh organisme agar organisme tersebut dapat tetap sehat . . . sebarang kekurangan, ketiadaan, atau ketiadasempurnaan yang dirasakan seseorang, sehingga merusak kesejahteraannya . .."19 Karena berpotensi untuk merusak kesejahteraan, maka seorang anak akan terus

\footnotetext{
${ }^{15}$ Kartini Kartono dan D. Gulo, "Character," dalam Kamus Psikologi (Bandung: Pionir Jaya, 2000), hlm. 64.

${ }^{16}$ J. P. Chaplin, "Character," dalam Kamus Lengkap Psikologi, pen., Kartini Kartono (Jakarta: PT Raja Grafindo Persada, 2002), hlm. 82.

${ }^{17}$ Mary Go Setiawani, Pembaruan Mengajar (Bandung: Yayasan Kalam Hidup, t.t), hlm. 20.

${ }^{18}$ Kartono dan Gulo, Kamus Psikologi, hlm. 299.

${ }^{19}$ Chaplin, Kamus Lengkap Psikologi, hlm. 20.
} 
mencari untuk memenuhi keperluan tersebut. Oleh karena keterbatasanketerbatasan pada dirinya, maka orang dewasalah yang harus memenuhi kebutuhan anak-anak; atau mendampingi mereka untuk memenuhi keperluannya.

\subsubsection{Karakteristik Umum Anak (0 - 12 Tahun $)^{20}$}

Segi Fisik: Mereka aktif dan enerjik, mereka mengalami pertumbuhan yang pesat.

Segi Mental: Anak-anak mencari dunia sekitar mereka. Perkembangan mental mereka berkembang pesat selama sebelas tahun pertama dalam kehidupan mereka. Mereka memiliki ketajaman intelektual, tapi masih terbatas. Mereka berpikir secara literal, spesifik dan belum mengerti hal abstrak, simbol dan penggabungan beberapa ide. Mengutip pendapat Jean Piaget, Clark menjelaskan empat tingkat proses berpikir pada anak-anak:

1. Periode sensorimotor (lahir -2 tahun). Pada tahap ini anak sudah dapat membedakan dirinya dengan obyek. Anak mengadakan gerakan-gerakan murni.

2. Periode preoperational thought atau berpikir pre-operasional (2-7 tahun). Di fase ini anak dapat mengklasifikasi, mengkategori tapi terbatas. Mereka juga dapat menilai benda yang dilihatnya.

3. Periode concrete operations atau operasi konkrit (7-11 tahun). Anak usia ini dapat memberi penjelasan, membandingkan, mengkontraskan; tapi masih dalam pola pikir yang logis.

4. Periode formal operation atau operasi formal (11-12 tahun). Anak pada fase ini mulai berpikir yang abstrak (hal-hal yang tidak berwujud atau yang tidak berbentuk) dan simbol agama baginya mulai memiliki makna.

Pada umumnya, anak-anak sangat cepat menghafal. Hafalan itu bisa melalui semua indra, yaitu mata, telinga, lidah, kulit dan hidung.

Segi Emosi (Perasaan): secara bertahap mereka belajar mengontrol diri. Usia 2-3 tahun mereka sangat sulit mengendalikan emosi. Anak-

\footnotetext{
${ }^{20}$ Robert E. Clark, "The Learner: Children," dalam Introduction to Biblical Christisn Education, ed., Werner C. Graendorf (Chicago: Moody Press, 1981), hlm. 129-30.
} 
anak akan mengembangkan kontrol emosi selama belajar berhubungan dengan orang lain.

Segi Sosial: pada umumnya anak-anak cenderung senang berteman. Selama bertumbuh mereka belajar berhubungan dengan orang lain dan menikmatinya.

Segi Spiritual: Mereka dapat mengerti hal rohani melalui percontohan dan penjelasan orang tuanya. Perkembangan intelektual mendahului kesiapan rohani, karena itu hal rohani harus diajarkan sejak dini. Anak-anak lebih terpengaruh oleh sikap dan tindakan daripada konsep yang mereka pelajari.

\subsubsection{Kebutuhan Anak (0 - 12 Tahun)}

Paling tidak ada tiga kebutuhan dari anak-anak.

\section{Pertama, Kebutuhan Jasmani}

1. "Memberi makanan, pakaian dan tempat tinggal. ${ }^{21}$

2. Menurut Jackson, yang dimaksud dengan kebutuhan jasmani adalah kebutuhan makanan, pakaian, perumahan dan pendidikan. $^{22}$

\section{Kedua, Kebutuhan Emosional}

Menurut Kent R. Brend dan Charles Williams, anak-anak mempunyai dua kebutuhan emosional yang mendasar. ${ }^{23}$

1. Kebutuhan untuk dicintai oleh orang tua.

Menurut Jacobsen, "Orang tua yang mengasihi anak-anak mereka akan bersedia mengorbankan diri dan kehendak mereka demi terciptanya suasana keluarga yang harmonis, dimana buah hati mereka dapat merasa bahwa ia benar-benar merupakan bagian dari keluarganya."24

${ }^{21}$ J. Verkuyl, Etika Kristen: Seksuil (Jakarta: PT. BPK Gunung Mulia, 1992), hlm. 174.

${ }^{22}$ Rex Jeckson, Pernikahan Dan Rumah Tangga (Malang: Penerbit Gandum Mas, 1978), hlm. 103.

${ }^{23}$ Kent R. Brend dan Charles Williams, Delapan Masalah Utama Orang TuaAnak (Jakarta: PT BPK Gunung Mulia, 1993), hlm. 3.

${ }^{24}$ Margaret Bailey Jacobsen, Ketika Anak Anda Bertumbuh (Bandung: Yayasan Kalam Hidup, 1977), hlm. 11. 
2. Kebutuhan untuk dimengerti.

Brend mengatakan, kedua kebutuhan ini merupakan unsur dasar bagi perkembangan harga diri anak yang harus diperhatikan oleh orang tua, karena mereka berharga di mata Tuhan. ${ }^{25}$ Ada kebutuhan emosional yang lain:

3. Kebutuhan untuk diperhatikan.

Jacobsen mengatakan mengatakan bahwa fungsi orang tua tidak dapat digantikan oleh harta benda atau pun hal-hal lainnya. Seorang anak membutuhkan ayah dan ibunya untuk bermain bersama, bercerita bersama, tertawa bersama, membacakan ceritanya bersama, serta ikut merasakan harapan dan keinginan ambisinya anak. ${ }^{26}$

Ruth Laufer dan Anni Dyck mengingatkan beberapa hal penting:

- Pandangan seorang anak mengenai dirinya sendiri akan berkembang sesuai dengan penilaian orang tua dan anggota keluarga lainnya, kemudian juga penilaian teman-teman sebaya.

- Tiap anak membutuhkan kasih dan suasana sukacita supaya dapat bertumbuh dengan baik. Kalau seorang anak diterima dan dibanggakan oleh keluarganya, anak itu merasa dirinya berharga. Itu juga menyebabkan dia tampak tentram, bahagia dan yakin akan dirinya.

- Sebaliknya, kalau seorang anak tidak diterima dengan rasa bangga oleh keluarganya, kalau tidak dirawat dengan baik, ia akan merasa kurang aman dan kurang berharga. Akan timbul perasaan rendah diri. Perasaan ini sulit dihilangkan di kemudian hari.

- Pikiran negatif mengenai dirinya sendiri yang berlebihan sama bahaya dengan penyakit kronis atau cacat tubuh.

\section{Ketiga, Kebutuhan Rohani}

Belandina menjelaskan demikian: "kebutuhan rohani bukanlah sekedar pelengkap bagi pertumbuhan anak, melainkan menjadi faktor

\footnotetext{
${ }^{25}$ Brend dan Williams, Delapan Masalah Utama Orang Tua-Anak, hlm. 3.

${ }^{26}$ Jacobsen, Ketika Anak Anda Bertumbuh, hlm. 12.
} 
penentu bagi tumbuh kembang anak, menentukan karakter seorang manusia kelak setelah dewasa."27

Sama seperti semua orang lainnya, anak adalah orang berdosa (Rm. 3:23), dan karena itu ia memerlukan Juruselamat. Ia juga perlu diajar dan dilatih dalam banyak hal sejak dini. Hal yang perlu diajar antara lain: ". . . berhubungan dengan cara berdoa, membaca Alkitab, menyanyi, menghafal ayat hafalan dan hidup yang berdasarkan kasih Kristus.

Dengan demikian, dari pertanyaan: "untuk siapa? ini para pengembang kurikulum Sekolah Minggu membagi kelas-kelas Sekolah Minggu berdasarkan tingkatan umur. Secara umum pembagiannya adalah seperti berikut: ${ }^{28}$

Kelas Kecil, terdiri dari kelompok anak balita dan batita. Mereka belum bisa fokus. Sehubungan dengan cerita-cerita Alkitab, anak-anak usia ini belum sadar akan perkembangan sejarah. Mereka belum tahu peristiwa-peristiwa dalam Perjanjian Lama (PL) mendahului peristiwaperistiwa dalam Perjanjian Baru (PB). Untuk itu, sebaiknya kurikulum untuk mereka diisi dengan cerita-cerita yang disajikan dalam satu tema bulanan, yang berpusat pada pengalaman mereka, seperti hidup dalam keluarga, penciptaan dan pemeliharaan Allah dan lain-lain. Cerita Alkitab dapat diambil dari PL dan PB, selama mendukung pokok yang diambil sebagai tema. Penggunaan media pembelajaran yang ada di lingkungan sekitar, seperti tumbuh-tumbuhan dan hewan; kertas gambar dengan kegiatan mewarnai. Tentunya dengan alokasi waktu hanya beberapa menit saja.

Kurikulum untuk kelompok kecil belum cocok disusun berdasarkan kalender gerejawi. Hanya beberapa bagian dari kalender yang dapat dipakai sebagai momentum, misalnya natal dalam kaitannya dengan keluarga kecil yang berbahagia.

Kelas Menengah atau Madya adalah kelompok anak usia 6-8 tahun. Anak-anak kelas menengah atau madya dapat menangkap cerita lebih lama. Namun demikian, anak-anak usia ini akan lebih suka ceritacerita atau materi pelajaran yang disajikan dengaan metode yang

\footnotetext{
${ }^{27}$ Yuprieli Hulu dan lainnya, Suluh Siswa 1: Bertumbuh dalam Kristus (Jakarta: BPK Gunung Mulia, 2015), hlm. 99-100.

${ }^{28}$ Laufer, Ruth dan Anni Dyck, Pedoman Pelayanan Anak 2 (Batu Malang: YPPII Departemen Pembinaan Anak dan Pemuda, t.t), hlm. 15-17.
} 
memberi kesempatan kepada mereka untuk membuktikan bahwa mereka "sudah pintar membaca."

Anak-anak pada usia ini mulai mengerti hubungan dari satu peristiwa ke peristiwa lainnya. Anak-anak kelas madya sudah mulai tertarik dengan kisah-kisah atau cerita-cerita ketokohan tetapi belum begitu besar ketertarikan mereka. Karena itu, kegiatan pembelajaran yang berisi aktivitas menggambar dan mewarnai; belajar sambil bermain masih perlu untuk kelompok usia ini. Mereka belum tertarik dengan konsep-konsep yang sifatnya doktrinal. Metode yang cocok bagi anak-anak ini adalah metode cerita, menulis, menggambar dan tanya jawab sederhana. Hal yang tidak bisa diabaikan ialah penggunaan media pembelajaran yang bervariasi.

Sebagaimana pada kelas kecil, kelas menengah pun sepertinya masih beberapa dalam kalender gereja yang dapat dijadikan acuan penyusunan kurikulum.

Kelas Besar yaitu kelompok anak usia 9-11 tahun. Kelompok usia ini sudah dapat mengerti peristiwa Alkitab dilihat secara keseluruhan dari segi sejarah, baik sejarah PL maupun PB. Mereka belajar mengenai pembebasan bangsa Israel dan perbudakan di Mesir dan perjalanan mereka di padang belantara selama berminggu-minggu, dan menyelidiki secara kronologis masa hakim-hakim, raja-raja dan kerajaan Israel yang terpecah menjadi dua, dan lainnya. Pada usia ini mereka mengagumi tokoh-tokoh dan meneladaninya.

Mulai pada kelas besar ini, pertimbangan menyusun kurikulum berdasarkan kalender gerejawi sudah lebih terbuka luas.

Kelas Tunas Remaja, usia 12 tahun. Pada usia ini, anak-anak berada pada ambang masa remaja. Metode cerita sudah jarang digunakan. Mereka sudah bisa menyelidiki Alkitab secara mandiri dengan metode yang menunjang. Guru dapat berfungsi sebagai pendamping.

Penyusunan kurikulum bertitik tolak dari kalender gerejawi yang dapat dilakukan. Mereka sudah dapat diajak untuk berdiskusi tentang hal-hal rohani, karena simbol-simbol agama baginya sudah mulai bermakna.

Dari pemaparan di atas, tentunya dapat simpulkan bahwa baik konten (isi) maupun pendekatan pembelajaran pada setiap tingkatan umur ini tidak sama. Demikian juga berhubungan dengan berapa banyak waktu yang dibutuhkan. 


\subsection{Konteks Mereka Yang Bagaimana?}

Apakah mereka anak-anak yang baru? Bagaimana dengan orang tua mereka: orang Kristen baru, kelompok yang baru dijangkau Injil, atau bagaimana? Pertanyaan-pertanyaan ini penting untuk dipikirkan, bukan hanya berhubungan dengan cara pendekatan, tetapi isi kurikulumnya.

\subsection{Konteks Mereka Yang Di Mana?}

Pertanyaan ini bersangkut paut dengan konteks adat dan budaya. Para pengembang kurikulum perlu memahami adat dan budaya setempat, sekaligus berusaha mengidentifikasinya. Patut diingat bahwa kemurnian firman Allah harus tetap dijaga, tidak boleh dicampurbaurkan, apa lagi dikompromikan. Banyak adat istiadat dan budaya yang menjujung tinggi norma dan etika dan tidak bertentangan dengan firman Tuhan. Tetapi harus diakui, ada saja yang bertentangan dengan firman Tuhan.

\section{Isinya Apa?}

Isi kurikulum Sekolah Minggu adalah Alkitab. Alkitab harus menjadi dasar kurikulum sekolah Minggu. Seluruh isi Alkitab adalah firman Allah yang diinspirasikan oleh Roh Kudus (2 Ptr. 1:20-21). Firman Allah diberikan untuk mengajar dan membawa kita kepada keselamatan. Seperti tertulis: "Ingatlah juga bahwa dari kecil engkau sudah mengenal Kitab Suci yang dapat memberi hikmat kepadamu dan menuntun engkau kepada keselamatan oleh iman kepada Tuhan Kristus Yesus. Segala tulisan yang diilhamkan Allah memang bermanfaat untuk mengajar, untuk menyatakan kesalahan, untuk memperbaiki kelakuan dan untuk mendidik orang dalam kebenaran." (2 Tim. 3:1516. ITB).

\section{Untuk Kapan?}

Sebuah pertanyaan yang berhubungan dengan waktu atau masa. Apakah untuk masa-masa pranatal, natal, paskah atau? Ini berhubungan 
dengan kalender gerejawi. Tetapi, penting untuk diingat, seperti pemaparan di atas; menyusun kurikulum tidak semata-mata berdasarkan kalender gerejawi. Kalender gerejawi dapat dijadikan acuan agar supaya terjadi pembelajaran langsung dengan suasananya.

Bila disimak secara seksama, kalender gerejawi disusun berdasarkan kehidupan dan pelayanan Yesus Kristus. Kalender gerejawi dapat dijadikan sebagai suatu acuan kurikulum yang bertujuan untuk menjelaskan karya Allah melalui kehidupan dan pelayanan Tuhan Yesus Kristus.

Secara garis besar, kalender gerejawi terdiri dari empat bagian besar, yaitu natal (atau kelahiran Kristus), Paskah (kematian dan kebangkitan Kristus), Kenaikan Kristus ke Surga dan Pentakosta.

\section{PENUTUP}

Mengembangkan atau menyusun kurikulum Sekolah Minggu sangat penting. Kepentingannya semata-mata berkaitan erat dengan peserta didik itu sendiri. Dasar dan pendekatan apapun yang digunakan, haruslah dibarengi dengan pertanyaan-pertanyaan penting, seperti: apakah cocok untuk anak-anak usia ini? Bisakah mereka memahaminya? Apakah ada cara praktis untuk mereka pahami dan lakukan? Dan banyak pertanyaan lainnya.

Dalam hubungannya dengan kalender gereja. Para penyusun kurikulum harus benar-benar bijak dalam menerapkannya. Sekali lagi, semuanya semata-mata harus berfokus dan dimulai dari peserta didik itu sendiri.

Generasi penerus, yaitu anak-anak, adik-adik, ponakan, tetangga atau anak-anak siapapun itu; kiranya akan terus menjadi perhatian pelayanan kita. Jangan biarkan dunia menjauhkan mereka dari kasih Allah dalam Yesus Kristus. Upaya penyusunan kurikulum yang sesuai, adanya kegiatan penataran, pelatihan atau apapun itu yang bertujuan untuk meningkatkan pelayanan; pastilah suatu bentuk kepedulian yang mengaminkan bahwa ANAK-ANAK ITU PENTING!!

Kiranya Allah Tritunggal akan terus memberkati usaha kita melayani anak-anak. Amin! 


\section{DAFTAR PUSTAKA}

Alkitab. Jakarta: Lembaga Alkitab Indonesia, 2010.

Brend, Kent R. dan Charles Williams. Delapan Masalah Utama Orang Tua-Anak. Jakarta: PT BPK Gunung Mulia, 1993.

Chaplin, J. P. "Character." Dalam Kamus Lengkap Psikologi. Diterjemahkan oleh Kartini Kartono. Jakarta: PT Raja Grafindo Persada, 2002.

Clark, Robert E. "The Learner: Children." Dalam Introduction to Biblical Christisn Education, ed., Werner C. Graendorf. Chicago: Moody Press, 1981.

Enklaar, I. H. dan E. G. Homrighausen. Pendidikan Agama Kristen. Jakarta: PT BPK Gunung Mulia, 2011.

Hulu, Yuprieli dan lainnya. Suluh Siswa 1: Bertumbuh dalam Kristus. Jakarta: BPK Gunung Mulia, 2015.

Jacobsen, Margaret Bailey. Ketika Anak Anda Bertumbuh. Bandung: Yayasan Kalam Hidup, 1977.

Jeckson, Rex. Pernikahan Dan Rumah Tangga. Malang: Penerbit Gandum Mas, 1978.

Kartono, Kartini dan D. Gulo, "Character." Dalam Kamus Psikologi. Bandung: Pionir Jaya, 2000.

Kristianto, Paulus Lilik. Prinsip Dan Praktik Pendidikan Agama Kristen. Yogyakarta: Penerbit ANDI, 2008.

Laufer, Ruth dan Anni Dyck. Pedoman Pelayanan Anak 2. Batu Malang: YPPII Departemen Pembinaan Anak dan Pemuda, t.t.

Lie, Paulus. Mengajar Sekolah Minggu Yang Kreatif. Yogyakarta: Penerbit Yayasan ANDi, 1997.

Nasution, S. Kurikulum Dan Pengajaran. Jakarta: PT Bumi Aksara, 1999.

Partin, Ronald L. Kiat Nyaman Mengajar Dalam Kelas. Jakarta: PT Indeks, 2009.

Riemer, G. Ajarlah Mereka: Pedoman Ilmu Katekese. Jakarta: Yayasan Komunikasi Bina Kasih / OMF, t.t. 
Setiawani, Mary Go. Pembaruan Mengajar. Bandung: Yayasan Kalam Hidup, t.t.

Sukmadinata, Nana Syaodih. Pengembangan Kurikulum Teori dan Praktek. Bandung: Penerbit PT Remaja Rosdakarya, 2001.

Verkuyl, J. Etika Kristen: Seksuil. Jakarta: PT. BPK Gunung Mulia, 1992.

Widodo. "Karakter." Dalam Kamus Ilmiah Populer. Yogyakarta: Penerbit Absolut, 2001. 